\title{
News from the IAWS
}

\author{
Robert Evans
}

(C) Springer-Verlag Berlin Heidelberg 2014

The 2014 Annual Plenary Meeting of the IAWS was organised in conjunction with the conference "Eco-efficient Resource Wood with special focus on hardwoods" in an exemplary cooperation between the University of West Hungary, Sopron, and BOKU University, Vienna, September 15-18. The organising committee was led by Professor Dr. Robert Nemeth and Professor Dr. Alfred Teischinger. The conference was an outstanding success, featuring in Hungarian television news.

Our highest honour, the Academy Lecture, was awarded to Professor Dr. Holger Militz, Chair of the Academy Board, who spoke on "Wood modification research from a European perspective". Professor Militz has served the wood science community as both an outstanding scientist with an exceptional publication record and a highly respected leader.

The conference programme included cultural and industrial excursions in Hungary and Austria, demonstrating a rich history of close cooperation and high achievement.

The 2014 IAWS PhD Award was won by Dr. Li Shuai. In presenting this award, the IAWS wishes to provide recognition to outstanding thesis/dissertation research at the $\mathrm{PhD}$ level by students throughout the world. The competition is limited to students receiving their degrees in other than their native country. The purpose is to foster and recognise cross-national interaction. Please see details of the nomination process on the Academy web page, and note that nominators are not restricted to the IAWS Fellowship.

The 2015 IAWS Plenary Meeting will be held in conjunction with the International Scientific Conference on Hardwood Processing, September 15-18, Québec City, Canada. More information can be found at http://www.ischp2015.org/.

2016 will be the fiftieth Anniversary of the IAWS which first met at the Centre Technique du Bois in Paris on 2 June 1966. The driving force behind the establishment of the IAWS was Professor Franz Kollmann, who became the first President. We are planning on special celebrations in 2016, and an announcement will be made soon. 